\title{
QUALITY ASSURANCES PRACTICES, TRAINING NEEDS AND INTERNATIONAL STUDENTS MOBILITY: ANALYSING THE NEXUSES
}

\author{
USMAN ABBO \\ ADAMU BASHIR \\ Othman Yeop Abdullah Graduate \\ School of Business \\ Universiti Utara Malaysia
}

\begin{abstract}
The role of education's quality in determining international students' choice of study destination was discussed by several studies. However, it only seems to have gained a huge prominence recently by constituting a theme in the quality management field involving empirical studies. In spite of such prominence the theme does not seems to provide sufficient empirical evidence forging a nexus between quality assurance practices, training needs and international student's mobility. This research work therefore attempts to fill this gap by examining how the search for quality education and training needs satisfaction play role in international student's mobility. Six dimensions of quality assurance in education were identified through extensive literature reviewed, three dimensions of training needs were equally revealed by the literature. Nine hypotheses were thus developed using these dimensions with the view to explain the relationship among the variables involved. The primary data for this study was obtained through a cross-sectional survey of International students in University Utara Malaysia with the aid of questionnaires, where a total of 150 respondents were selected randomly. Partial Least Squares (PLS) method was adopted in analysing the collected data with smartPLS 2.0 to determine the relationship involved. The result supported the relationship between organizational needs, Tangibility of facilities, Nature of service delivery and international student's mobility, while the other six relationships were not supported.
\end{abstract}

Keywords: International students, quality assurance, training needs, education, Malaysia

\section{Introduction}

Quality assurance frameworks are gradually becoming very vital to the growth and survival of higher educational institutions which primarily serve as a mechanism for the enhancement of competitiveness and organizational viability (Strong \& Taylor, 2011). Educational institutions are looking to revamp their level of effectiveness in both capacity and functions, in which quality assurance frameworks are considered the proper mechanisms for the achievement of these goals (Ganguli \& Roy, 2011; Usman, Romle \& Qader, 2015). Several frameworks for quality management and quality assurance practices have been developed; however, the most broadly utilized one is the ISO9000 series. This is established on eight quality management standards which involve sound leadership, client center, management by objective, system approach to management, persistent improvement, process management and strategic decision-making with a win-win outcome.

Quality assurance frameworks in higher education recently keep becoming prominent in the European and American societies (Usman, 
Romle and Qader, 2015). This development could be ascribed to the way in which greater emphasis is placed on skill and expertise as crucial components for higher productivity in which the most critical factor in deciding the rate of development of a given society is hinged on the proportion of its manpower that have access to quality education (Okebukola, 2012). This development has invariably created an increasing demand for quality education globally, where both public and private organizations appear to be very meticulous and quality conscious in their recruitment and training programs (Guerry \& De Feyter, 2012). This compels some organizations and individuals to start searching for quality education across their national boundaries (Usman, Romle \& Qader, 2015).

Interestingly, the forces of globalization have in the second half of the twentieth century, accounted for an unprecedented increase in international students' mobility. Increasingly, Universities in the Euro-American societies rely on international student's enrollment for their revenue and to meet up with internationalization targets (Wilkins \& Huisman, 2011). Additionally, the expansion in transnational higher education (where learners are situated in a nation other than the one in which the awarding university is based) has profited both host nations (e.g. human capital development) and source nations (e.g. providing new sources of revenue). Information gathered by the OECD revealed that international students' mobility has shown a significant increment in the course of the most recent three decades more than the total global migration (King, Findlay \& Ahrens, 2010). Precisely, international students' mobility increased by 52\% between 1998 to 2012 (Bhandari \& Blumenthal, 2013).

This movement is usually explained in literature from two important viewpoints "the push" and "the pull" where the former depicts a condition in the prospective student's country which compels him/her to search for education elsewhere; the latter connotes a condition in the host nation which serves as a point of attraction to the international student (Choudaha \& Chang, 2012).
Several studies were conducted in order to determine the factors influencing international students' mobility where factors such as financial implication (Dwenger, Storck \& Wrohlich, 2012), institutional reputation (Tin, Ismail, Othman, \& Sulaiman, 2015), learning facilities (Bettinger, Long, Oreopoulos \& Sanbonmatsu, 2012), culture (Zain, Jan \& Ibrahim, 2013), and attitude toward extra-curricular activity (Chung, 2012) were identified. A critical review of the above works demonstrates that none of them analyzed the intrinsic elements, for example, the need to satisfy the training needs of the forthcoming international students and the needs to satisfies the manpower policy objectives of his/her country/organization back home; hence a noteworthy contribution of this work is to assess the conceivable nexus between the quality assurance practices of the chosen university, the training needs of the prospective international students, as well as the satisfaction of the manpower needs of his/her country on the one hand and the choice to come to Malaysia for studies. This work was therefore developed along these lines, to evaluate the nature of the relationship that exists among the three variables and also to determine the level at which such relationship could bring about accomplishing the training needs of the international students.

The general objective of this study is to assess the relationship between quality education, the training needs and international students' mobility. In specific terms the study has the following objectives:

1. To ascertain the relationship between the training needs of the international students and their decision to study abroad.

2. To find out whether the quality of the universities has influenced the decision of the international students to study abroad.

3. To find out the extent to which the students' employers back home are involved in their decision to study abroad.

4. To examine the relationship between the perceived service quality of Malaysian universities and the training needs satisfaction of the prospective international students. 


\section{Conceptual Framework}

Owila and Aspinwall (1996) developed a conceptual framework that covers six essential variables delineating quality measurement in view of the three distinctive ways to deal with quality in higher education. It includes reliability, tangible, attitude, competence, delivery, and content. This study therefore improves on the above model by devising a new model which covers the six dimensions of quality and the three dimensions of training needs with the view to explain international students' mobility which was not covered by the previous models.

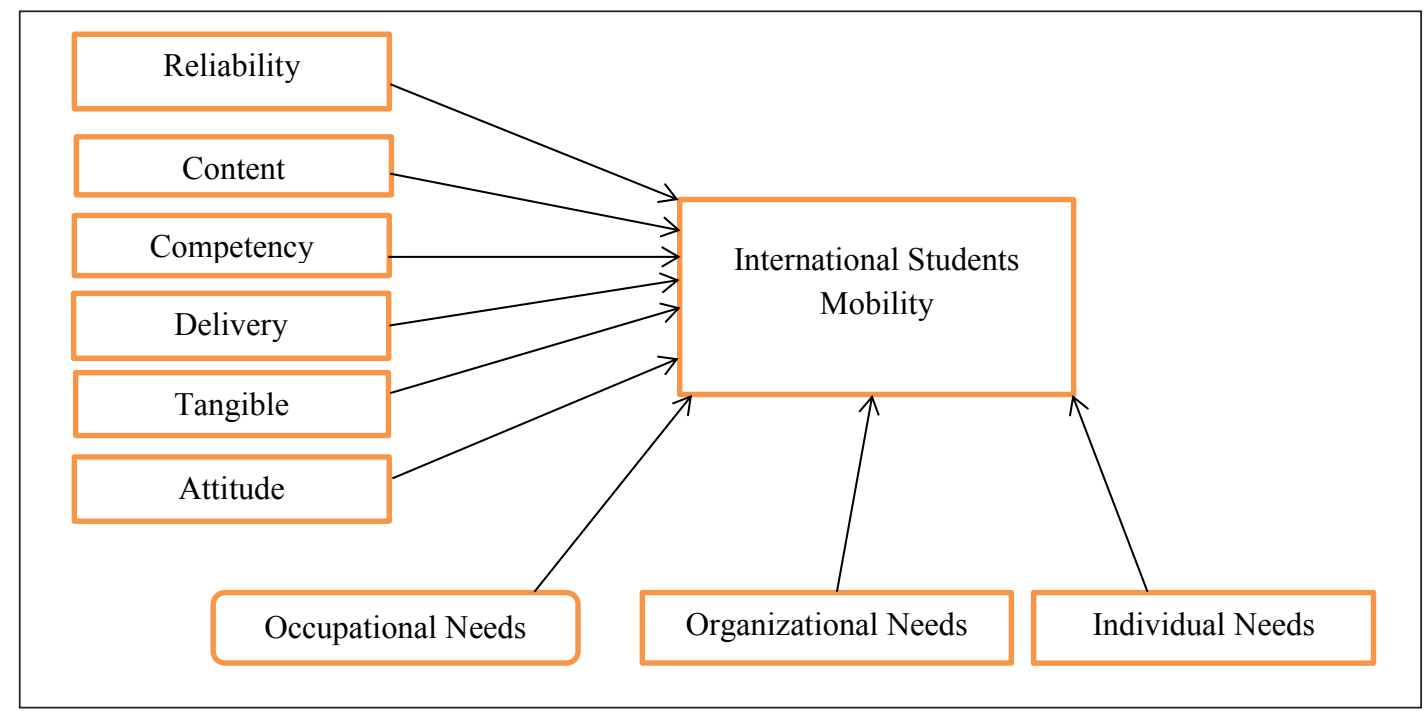

Figure 1. Conceptual framework

\section{Hypotheses Development}

Extensive review of the literature on the Quality Management field suggests that quality education falls under the service quality criteria which are measured using the following dimensions: tangibility of facilities, competency of academic staff, attitude of academic staff, content of syllabus, method of delivery, reliability of facilities and staff (Ganguli \& Roy, 2011; Jemmasi, Strong \& Taylor, 2011; Siddiqi, 2011). Similarly, the literature revealed that training needs have three important dimensions as follows: organizational needs, occupational needs and individual needs (Onansanya, 2005; Berger, Hasking \& Reupert, 2014). On the basis of these, the following hypotheses were thus developed:

H1 : There is a positive relationship between the tangibility of university facilities and international students' choice of study destinations.
$\mathrm{H} 2$ : There is a positive relationship between the competency of academic staff and international students' choice of study destinations.

H3 : There is a positive relationship between the staff's attitude and international students' choice of study destinations.

$\mathrm{H} 4$ : There is a positive relationship between the university's syllabus content and international students' choice of study destinations.

H5 : There is positive relationship between the university's service delivery and international students' choice of study destinations.

H6 : There is a positive relationship between the reliability of facilities and international students' choice of study destinations.

$\mathrm{H} 7$ : There is a positive relationship between organizational needs and 
international students' choice of study destinations.

H8 : There is a positive relationship between occupational needs and international students' choice of study destinations.

H9 : There is a positive relationship between individual needs and international students' choice of study destinations.

\section{Methodology}

In this study, primary sources of information were used to produce the data needed for investigation. The instrument used was a questionnaire survey that was adapted by the researcher on the premise of previous researches. Taking into cognizance the research purpose, frame-work and hypotheses this work adopted a quantitative method in an attempt to answer some key questions about the factors influencing international students' mobility. The study employed a cross-sectional survey design in order to facilitate the data collection procedure suitable for this work. The study also utilized a personal-administered questionnaire which according to Sekran (2010) depicts "a survey whereby the researcher or member of the research team can directly collect all the completed response within a short period of time." Due to time constraints, the simple random sampling procedure was used to select the respondents. Based on Krejcie and Morgan (1970), this study decided to choose 150 students as our sample. The units of analysis for this study were the international students in Universiti Utara Malaysia. The survey instrument consisted of two parts. In part A of the questionnaire, the survey respondents were asked to state their level of agreement of each statement for six dimensions of quality assurance practices in education (reliability, content, competency, delivery, tangibility, attitude) and three dimensions of training needs (occupational, organizational, individual) on a five-point Likert scale (1 represents "strongly disagree" 2 represents "disagree" 3 represents "neutral" 4 represents "agree" and 5 represents "strongly agree";). According to Cooper and Donald (2000), this kind of scale is thought to be an interim scale. Hence, estimation of focal inclination and its scattering can be made. The Partial Least Square (PLS) with the aid of SmartPLS 2.0 was used to analyze the data gathered.

\section{Results and Discussion Internal Consistency Reliability}

Internal consistency reliability refers to the extent to which all items on a particular (sub) scale measure the same concept (Bijttebier, Delva, Vanoost, Bobbaers, Lauwers \& Vertommen, 2000; Sun et al., 2007). Cronbach's alpha coefficient and composite reliability coefficient are the most commonly used estimators of the internal consistency reliability of an instrument in organizational research (e.g. Bacon, Sauer \& Young, 1995; McCrae, Kurtz, Yamagata \& Terracciano, 2011; Peterson \& Kim, 2013). The interpretation of internal consistency reliability using composite reliability coefficient was based on the rule of thumb provided by Bagozzi and Yi (1988) as well as Hair, Ringel and Sarstedt (2011), who suggest that the composite reliability coefficient should be at least .70 or more. In this study the composite reliability coefficient of each latent construct ranged from .805 to .894 , with each exceeding the minimum acceptable level of .70, suggesting adequate internal consistency reliability of the measures used in this study (Bagozzi\& Yi, 1988).

\section{Convergent Validity and Discriminant Validity}

Convergent validity refers to the extent to which items truly represent the intended latent construct and indeed correlate with other measures of the same latent construct (Hair, Black, Babin \& Anderson, 2006). Convergent validity was assessed by examining the Average Variance Extracted (AVE) of each latent construct, as suggested by Fornell and Larcker (1981). To achieve adequate convergent validity, Chin (1998) recommends that the AVE of each latent construct should be .50 or more. Following Chin (1998), the AVE values exhibited high 
loadings $(>.50)$ on their respective constructs, indicating adequacy. Discriminant validity, on the other hand, refers to the extent to which a particular latent construct is different from other latent constructs (Duarte \& Raposo, 2010). In the present study, discriminant validity was ascertained using AVE, as suggested by Fornell and Larcker (1981). This was achieved by comparing the correlations among the latent constructs with square roots of average variance extracted (Fornell \& Larcker, 1981). To achieve adequate discriminant validity, Fornell and Larcker (1981) suggest that the square root of AVE should be greater than the correlation among the latent constructs. The values of the average variances extracted ranged between .524 and .737 , suggesting acceptable values. The square roots of the average variances extracted were all greater than the correlations among the latent constructs, suggesting adequate discriminant validity (Fornell \& Larcker, 1981).

Table 1

Test of Hypotheses

\begin{tabular}{llccccl}
\hline Hypotheses & Relationship & $\begin{array}{c}\text { Beta } \\
\text { value }\end{array}$ & $\begin{array}{c}\text { Std. } \\
\text { error }\end{array}$ & t value & p value & Decision \\
\hline H1 & Tangible -> Mobility & -0.501 & 0.205 & 2.441 & 0.008 & Supported \\
\hline H2 & Competency -> Mobility & 0.050 & 0.146 & 0.339 & 0.368 & Not Supported \\
\hline H3 & Attitude -> Mobility & -0.049 & 0.173 & 0.283 & 0.389 & Not Supported \\
\hline H5 & Content -> Mobility & 0.182 & 0.160 & 1.136 & 0.129 & Not Supported \\
\hline H6 & Delivery -> Mobility & 0.232 & 0.144 & 1.616 & 0.054 & Supported \\
\hline H7 & Reliability -> Mobility & -0.039 & 0.150 & 0.262 & 0.397 & Not Supported \\
\hline H8 & Organization -> Mobility & 0.272 & 0.117 & 2.317 & 0.011 & Supported \\
\hline H9 & Occupational -> Mobility & 0.110 & 0.101 & 1.091 & 0.139 & Not Supported \\
\hline H9 & Individual -> Mobility & -0.051 & 0.129 & 0.399 & 0.345 & Not Supported \\
\hline
\end{tabular}

\section{Assessment of Effect Size (f2)}

Effect size indicates the relative effect of a particular exogenous latent variable on endogenous latent variable(s) in the $R$-squared (Chin, 1998). It is calculated as the increase in $R$-squared of the latent variable to which the path is connected, relative to the latent variable's proportion of unexplained variance (Chin, 1998). Table 4.12 shows the respective effect sizes of the latent variables of the structural model.

As indicated in Table 2, the effect sizes for competency, content, delivery, reliability, tangibility and attitude, on choice of study destination, were $0.01,0154,020,000, .156$ and
0.01, respectively. Hence, following Cohen's (1988) guideline, the effects sizes of these four exogenous latent variables on interpersonal deviance can be considered as none, small, small, none, medium, and none respectively. Furthermore, Table 2 indicates that the effect sizes for individual needs, occupational needs and organizational needs on the choice of study destination were $.000, .008$ and .041 respectively. Similarly, on the basis of Cohen's (1988) guideline for interpretation of the effect size, the results suggest that the effect sizes of these four exogenous latent variables on the choice of study destination can be considered as none, small, and small respectively. 
Table 2

f2 Effect Size

\begin{tabular}{llcccl}
\hline Endogenous & \multicolumn{1}{c}{ Exogenous } & $\begin{array}{c}\text { R-squared } \\
\text { Included }\end{array}$ & $\begin{array}{c}\text { R-squared } \\
\text { Excluded }\end{array}$ & f-squared & Effect size \\
\hline Mobility & Competency & .290 & .289 & .001 & None \\
& Content & .290 & .279 & .015 & Small \\
& Delivery & .290 & .276 & .020 & Small \\
& Individual & .290 & .290 & .000 & None \\
& Occupational & .290 & .284 & .008 & Small \\
& Organization & .290 & .261 & .041 & Small \\
& Reliability & .290 & .290 & .000 & None \\
& Tangible & .290 & .179 & .156 & Medium \\
& Attitude & .290 & .289 & .001 & None \\
\hline
\end{tabular}

\section{Assessment of Predictive Relevance}

The present study also applied the StoneGeisser test of predictive relevance of the research model using blindfolding procedures (Geisser, 1974; Stone, 1974). The Stone-Geisser test of predictive relevance is usually used as a supplementary assessment of goodness-offit in partial least squares structural equation modeling (Duarte \& Raposo, 2010). Even though this study used blindfolding to ascertain the predictive relevance of the research model, it is worth noting that according to Sattler, Völckner, Riediger and Ringle (2010) "blindfolding procedure is only applied to endogenous latent variables that have a reflective measurement model operationalization" (p.320). The reflective measurement model "specifies that a latent or unobservable concept causes variation in a set of observable indicators (McMillan \& Conner,
2003 , p. 1). Hence, because all endogenous latent variables in the present study were reflective in nature, the blindfolding procedure was applied mainly to these endogenous latent variables.

In particular, a cross-validated redundancy measure $\left(Q^{2}\right)$ was applied to assess the predictive relevance of the research model (Chin, 2010; Geisser, 1974; Hair \& Sarstedt, 2013; Ringle, Sarstedt \& Straub, 2012b; Stone, 1974). The $Q^{2}$ is a criterion to a measure how well a model predicts the data of omitted cases (Chin, 1998; Hair \& Sarstedt, 2014). According to Henseler, Ringle and Sinkovics, (2009), a research model with $Q 2$ statistic (s) greater than zero is considered to have predictive relevance. Additionally, a research model with higher suggests more predictive relevance. Table 3 presents the results of the cross-validated redundancy $Q^{2}$ test.

Table 3

Redundancy Q2 Value

\begin{tabular}{crrr}
\hline Total & SSO & \multicolumn{1}{c}{ SSE } & 1-SSE/SSO \\
\hline Mobility & 786 & 658.5537 & 0.1621 \\
\hline
\end{tabular}


As shown in Table 3 the cross-validation redundancy measure $\mathrm{Q}^{2}$ for all endogenous latent variables are above zero, suggesting predictive relevance of the model (Chin, 1998; Henseler et al., 2009).

Table 4

Summary of Hypotheses Testing

\begin{tabular}{lll}
\hline Hypothesis & Statement & Finding \\
\hline$H 1$ & $\begin{array}{l}\text { There is positive relationship between tangibility and international } \\
\text { students' mobility. }\end{array}$ & Supported \\
H2 & $\begin{array}{l}\text { There is positive relationship between staff competency and international } \\
\text { students' mobility. }\end{array}$ & Not supported \\
H3 & $\begin{array}{l}\text { There is a positive relationship between the attitude of staff and } \\
\text { international students' mobility. }\end{array}$ & Not supported \\
H4 & $\begin{array}{l}\text { There is a positive relationship between syllabus content and international } \\
\text { students' mobility. }\end{array}$ & Not supported \\
H5 & $\begin{array}{l}\text { There is a positive relationship between the university's service Delivery } \\
\text { and international students' mobility. }\end{array}$ & Supported \\
H6 & $\begin{array}{l}\text { There is a positive relationship between Reliability of university staff } \\
\text { and international students, mobility. }\end{array}$ & Not supported \\
H7 & $\begin{array}{l}\text { There is a positive relationship between organizational needs and choice } \\
\text { of study destination. }\end{array}$ & Supported \\
There is a positive relationship between the occupational needs of & Not supported \\
international students' and their mobility. & \\
There is a positive relationship between individual training needs and & Not supported \\
& international students' mobility. & \\
\hline
\end{tabular}

The main objective of this study is to examine the relationships between quality assurance, training needs and international students' mobility. Overall, this study has succeeded in advancing the current understanding of the key determinants of the factors influencing international students' choice of study destinations by providing answers to the following research questions: first; is the decision to study abroad by the international students influenced by their training needs? Second, is there a relationship between the university quality assurance practice and the decision by international students to come for study? Third, to what extent do the organizations/employers of the prospective international students affect their decisions to study abroad? Fourth, what is the relationship between the perceived service quality of the Malaysian universities and training needs satisfaction of the prospective international students?

Regarding the direct relationship between the exogenous latent variable and the endogenous latent variables, the findings of this study indicated that of the 9 hypotheses, only 3 were supported. The results of the PLS path model showed that university service delivery was significantly and positively related to the choice of study destination; organizational training need was also found to be significantly and positively related to the choice of study destination. The findings further revealed that tangibility of university service was significantly and positively related to the choice of study destination. All these are consistent with previous findings (Mazzarol \& Soutar, 2002).

In contrast, the attitude of the institution was 
found not to be significantly and positively related to the choice of study destination. The results also revealed that the competency of academic staff does not influence the choice of study destination by international students. The results further revealed that the contents of the syllabus do not influence international students' choice of study destinations; it also showed that the reliability of the university's staff does not influence the choice of study destinations. In terms of training needs the results revealed that occupational needs do not influence the choice of study destinations It further revealed that individual training needs does not influence their choice of study destinations.

\section{Limitations and Future Research Directions}

Even though this study has provided support for a number of the hypothesized relationships between the exogenous and endogenous variables, the findings have to be interpreted with consideration of the study's limitations. Firstly, the present study adopts a cross-sectional design which does not allow causal inferences to be made from the population. Therefore, a longitudinal design in future needs to be considered to measure the theoretical constructs at different points in time to confirm the findings of the present study.

Secondly all elements of the target population were not captured, as such, the extent to which sample size represents the entire population cannot be known (Lohr, 2009). The use of only one university (UUM) has limited the extent to which the findings of the study can be generalized to the population. Therefore, future research needs to go beyond this so that one sample frame is obtained and the findings of the study can be generalized to the entire international students in several universities in Malaysia.

Thirdly, the present study offers quite limited generalizability as it focused mainly on students from Africa and the Middle East. Consequently, additional work is needed to include students from other continents in order to generalize the findings. Private universities should also be studied and compared with public institutes of higher education. Fourthly, the majority of the respondents of this study were post-graduate students due to the few number of undergraduate students, and as findings by Quintal and Taylor (2005) indicate undergraduates students are in a better position to appraise the service quality of an educational institution.

\section{Conclusion}

In general parlance, the present study has provided additional evidence to the growing body of knowledge concerning the relationship between quality assurance, training needs and the choice of study destinations by international students. Results of this study lend support to the key theoretical propositions. In particular, the current study has successfully answered all of the research questions and objectives despite some of its limitations. While there are many studies that have examined the underlying causes of international students' mobility, the present study addressed the theoretical gap by incorporating training needs and quality assurance as significant independent variables. In addition to the theoretical contributions, the results of this study provide some important practical implications to organizations and managers. Furthermore, based on the limitations of the current study, several future research directions were drawn. In conclusion, the present study has added valuable theoretical, practical, and methodological ramifications to the growing body of knowledge in the field of quality management, educational quality assurance and human resource management, particularly manpower training and development.

\section{References}

Arambewela, R., \& Hall, J. (2009). An empirical model of international student satisfaction. Asia Pacific Journal of Marketing and Logistics.

Bagozzi, R., \& Yi, Y. (1988). On the evaluation of structural equation models. Journal of the Academy of Marketing Science. 
Barclay, D., Higgins, S., \& Thompson, R. (1995). The partial least squares approach to causal modeling: Personal computer adoption and use as an illustration. Technology Studies.

Barker, C., Pistrang, N., \& Elliott, R. (2003). Research methods in clinical psychology: An introduction for students and practitioners (2nd ed.). Chichester: John Wiley and Sons.

Behrman, J. R., Rosenzweig, M. R., \& Taubman, P. (1996). College choice and wages: Estimates using data on female twins. The Review of Economics and Statistics, 672-685.

Berger, E., Hasking, P., \& Reupert, A. (2014). Response and training needs of school staff towards student selfinjury. Teaching and Teacher Education, 44, 25-34.

Berry, L., \& Parasuraman, A. (1992). Prescription for service quality. American organizational dynamics, 20.

Bettinger, E. P., Long, B. T., Oreopoulos, P., \& Sanbonmatsu, L. (2012). The role of application assistance and information in college decisions: Results from the $\mathrm{h} \& \mathrm{r}$ block fafsa experiment*. The Quarterly Journal of Economics, 127(3), 1205-1242.

Bhandari, R., \& Blumenthal, P. (2013). International students and global mobility in higher education: National trends and new directions. International Studies, 1(11), 316-317.

Bijttebier, P., Delva, D., Vanoost, S., Bobbaers, H., Lauwers, P., \& Vertommen, H. (2000). Reliability and validity of the critical care family needs inventory in a dutch-speaking Belgian sample. Heart\& Lung: The Journal of Acute andCritical Care.

Cabrera, A. F., \& S, M. La NASA. (2000). Understanding the college-choice process. New Directions for Institutional Research.

Chalvet, V. (2004). Guide quality assurance at higher education institutions: A Progress report and the results of a survey of the quality assurance project, Bonn.
Chapman, D. W. (1981). A model of student college choice. The Journal of Higher Education, 490-505.

Chin, W. (2010). How to write up and report PLS analyses. In V. Esposito Vinzi, W.W. Chin, J. Henseler\& H. Wang (Eds.), Handbook of Partial Least Squares: Springer, Berlin Heidelberg, pp. 655-690.

Chin, W. W. (1998). The partial least squares approach to structural equation modeling. In G. A. Marcoulides (Ed.). Modern Methods for Business Research (pp. 295-336). Mahwah, New Jersey: Laurence Erlbaum Associates.

Chin, W. W., Marcolin, B. L., \& Newsted, P. R. (2003). A partial least squares latentvariable modeling approach for measuring interaction effects: Results from a Monte Carlo Simulation study and an electronic-mail emotion/ adoption study. Information Systems Research.

Choudaha, R., \& Chang, L. (2012). Trends in international student mobility. World Education News \& Reviews, 25(2).

Chung, A. S. (2012). Choice of for-profit college. Economics of Education Review, 31(6), 1084-1101.

Cohen, J. (1988). Statistical power analysis for the behavioral sciences. Hillsdale, NJ: Lawrence Erlbaum Associates.

Cooper, Donald, R. (2000). Business Research Method (7th ed.) New York, McGrawHill/Irwin

Crosby, P. B. (1979), Quality is Free: The Art of Making Quality Certain, New American Library, and New York, NY.

Duarte, P., \& Raposo, M. (2010). A PLS model to study brand preference: An application to the mobile phone market. In V. Esposito Vinzi, W. W. Chin, J.Henseler \& H. Wang (Eds.). Handbook of Partial Least Squares.

Dwenger, N., Storck, J., \& Wrohlich, K. (2012). Do tuition fees affect the mobility of university applicants? Evidence from a natural experiment. Economics of Education Review, 31(1), 155-167. 
Fornell, C., \& Larcker, D. F. (1981). Evaluating structural equation models with unobservable variables and measurement error. Journal of Marketing Research.

Ganguli, S., \& Roy, S. K. (2011). Generic technology-based service quality dimensions in banking: Impact on customer satisfaction and loyalty. International Journal of Bank Marketing, 29(2), 168-189.

Geisser, S. (1974). A predictive approach to the random effect model. Biometrika.

Goetsch, D.L., \& Davis S.B. (2003). Quality management: Introduction to total quality management for production, processing and services. (4th ed.), New Jersey, Prentice Hall.

Guerry, M. A., \& De Feyter, T. (2012). Optimal recruitment strategies in a multi-level manpower planning model. Journal of the Operational Research Society, 63(7), 931-940.

Hair, J. F., Black, W. C., Babin, B. J., \& Anderson, R. E. (2010). Multivariate data analysis ( $7^{\text {thed.). }}$. Upper Saddle River, New Jersey: Prentice Hall.

Hair, J. F., Black, W. C., Babin, B. J., Anderson, R. E., \& Tatham, R. L. (2006). Multivariate data analysis (6th ed.). Upper Saddle River, NJ: Pearson/ PrenticeHall.

Hair, J. F., Hult, G. T. M., Ringle, C. M., \& Sarstedt, M. (2014). A primer on partialleast squares structural equation modeling (PLS-SEM). Thousand Oaks: Sage Publications.

Hair, J. F., Money, A. H., Samouel, P., \& Page, M. (2007). Research method for business. West Sussex, England: John Wiley \& Sons Ltd.

Hair, J. F., Ringle, C. M., \& Sarstedt, M. (2011). PLS-SEM: Indeed a silver bullet. Journal of Marketing Theory and Practice.

Hair, J. F., Ringle, C. M., \& Sarstedt, M. (2013). Partial least squares structural equation modeling: Rigorous applications, better results and higher acceptance. Long Range Planning.
Hair, J. F., Sarstedt, M., Ringle, C. M., \& Mena, J. A. (2012). An assessment of the use of partial least squares structural equation modeling in marketing research. Journal of the Academy of Marketing Science.

Henseler, J., \& Chin, W. W. (2010a). A comparison of approaches for the analysis of interaction effects between latent variables using partial least squares path modeling. Structural Equation Modeling: AMultidisciplinary Journal,

Henseler, J., \& Chin, W. W. (2010b). A comparison of approaches for the analysis of interaction effects between latent variables using partial least squares path modeling. Structural Equation Modeling.

Henseler, J., \& Fassott, G. (2010a). Testing moderating effects in PLS path models: An Illustration of Available Procedures. In V. Esposito Vinzi, W. W. Chin, J. Henseler \& H. Wang (Eds.), Handbook of Partial Least Squares: Concepts, Methods and Applications.

Henseler, J., \& Fassott, G. (2010b). Testing Moderating Effects in PLS Path Models:An illustration of available procedures. In V. Esposito Vinzi, W. W. Chin, J. Henseler \& H. Wang (Eds.), Handbook of Partial Least Squares.

Henseler, J., Ringle, C. M., \& Sinkovics, R. R. (2009). The use of partial leastSquares path modeling in international marketing. In R. R. Sinkovics \& P. N.Ghauri (Eds.), Advances in International Marketing (Vol. 20, pp. 277-320). Bingley: Emerald.

Henseler, J., \& Sarstedt, M. (2013). Goodnessof-fit indices for partial least squares path modeling. Computational Statistics.

Henseler, J., Wilson, B., Götz, O., \& Hautvast, C. (2007). Investigating the moderating role of fit on sports sponsorship and brand equity. International Journal of Sports Marketing \& Sponsorship,

Hill, F. M. (1995). Managing service quality in higher education: The role of the 
student as primary consumer, Quality Assurance in Education.

Hill, Y., Lomas, L., \& MacGregor, J. (2003). Students' perceptions of quality in higher education. Quality Assurance in Education.

Jemmasi, M., Strong, K. C., \& Taylor, S. A. (2011). Measuring service quality for strategic planning and analysis in service firms. Journal of Applied Business Research (JABR), 10(4), 2434.

Krejcie, R., \& Morgan, D. (1970). Determining sample saiz for research activities. Educational and Psychological Measurement.

Okebukola, P. (2006). The state of Nigerian universities In Proceedings of the Summit on Higher Education in Nigeria. Published by Heinemann Educational Books (Nig.) Plc (Eds.), Aborishade and Okebukola.

Okebukola, P. (2008). Quality assurance in Nigeria University system: Role of stakeholders. In: Proceedings of a Symposium Organized by the Federal University of Technology, Akure.

Onasanya, C.M.D. (2005). Effective personnel management and industrial relations. Ibadan, Longman publishers.

Owlia, M. S., \& Aspinwall, E. M. (1996). A framework for the dimensions of quality in higher education. Quality Assurance in Education, 4(2), 12-20.

Parasuraman, A., Zeithaml, V.A., \& Berry, L.L. (1985). A conceptual model of service quality and its implications for future research. Journal of Marketing.

Parasuraman, N., Zeitmal, V.A., \& Berry, L.L. (1988). SERVQUAL: A multipleitem scale for measuring consumer perceptions of service quality, Journal of Retailing.

Peterson, R. A., \& Kim, Y. (2013). On the relationship between coefficient alpha and composite reliability. Journal of Applied Psychology.
Qureshi, S. (1995). College accession research: New variables in an old equation. Journal of Professional Services Marketing.

Ringle, C. M., Sarstedt, M., \& Straub, D. (2012). A critical look at the use of PLS-SEM in MIS Quarterly. MIS Quarterly (MISQ), 36(1).

Siddiqi, K. O. (2011). Interrelations between service quality attributes, customer satisfaction and customer loyalty in the retail banking sector in Bangladesh. International Journal of Business and Management, 6(3), p12.

Stone, M. (1974). Cross-validatory choice and assessment of statistical predictions. Journal of the Royal Statistical Society. Series B (Methodological).

Sekaran \& Bougie, R. (2010). Research methods for business: A skill building approach. UK: John Wiley \& Sons.

Tin, P. B., Ismail, R., Othman, N., \& Sulaiman, N. (2012). Globalization and the factors influencing households' demand for higher education in Malaysia. International Journal of Education and Information Technologies, 6(3), 269278.

Usman, A., Romle, A. R., \& Qader, M. M. (2015). Examining the relationships between quality assurance, training need and choice of study destination: A study of Nigerian students in UUM. International Journal of Economics and Financial Issues, 5(1S), $1-6$.

Zain, O. M., Jan, M. T., \& Ibrahim, A. B. (2013). Factors influencing students' decisions in choosing private institutions of higher education in Malaysia: A structural equation modelling approach. Asian Academy of Management Journal, 18(1), 75-90.

Zeithaml, V. (1987). Defining and relating price, perceived quality and perceived value, Request No 87-101, Marketing Science Institute, Cambridge. 